\title{
PENINGKATAN KINERJA BIDANG KESEHATAN, MOTIVASI DAN PELAYANAN PRIMA
}

\author{
Harries Madiistriyatno dan Adi Setiawan \\ Sekolah Tinggi Managemen IMMI Jakarta, Indonesia \\ Email: harries.madi@gmail.com dan stimaimmijakarta@gmail.com
}

\begin{abstract}
The purpose of this study is anything to know how big the appearance of the field of health, pelitif and excellent service This research method of descriptive statistical analysis in a double way double with the method of double pardigma two free variables and one variable variable. each variable is a promise, the 33rd relationship, one by one or good. analysis of which analysis between analysis variables with Health Field Performance may be $Y=47.215+0.123 X 2$ and double regression related between variables and excellent service together with health field performance again $Y=27.594+0.370 X 1+0.127 X 2$. From the results of this study, there is an influence between the capabilities of the health sector in puskesmas which is linked to the research hypothesis, namely there is an influence between the health sector and the health sector, there is the influence of excellent services with the field of health, and there is the influence of excellent capabilities and services together with the field of health in the Tanjungsari Health Center Bogor Regency.
\end{abstract}

Keywords: motivation; excellent; servants

\begin{abstract}
Abstrak
Tujuan penelitian ini adalah untuk mengetahui seberapa besar kinerja bidang kesehatan, motivasi dan pelayanan prima Penelitian ini menggunakan metode analisis statistic deskriptif dengan menggunakan pendekatan ganda dengan mengedepankan pardigma ganda dua variabel bebas dan satu variabel terikat. masing-masing variabel adalah kinerja, hubungan diantara ketiganya, satu persatu maupun secara persamaan. analisis yang digunakan adalah analisis tersebut didapat persamaan regresi antara variabel motivasi dengan Kinerja Bidang Kesehatan adalah $\mathrm{Y}=47,215+0,123 \mathrm{X} 2$ dan regresi ganda yang menyatakan hubungan antara variabel motivasi dan pelayanan prima secara bersama-sama dengan kinerja bidang kesehatan adalah $\mathrm{Y}=27,594+0,370 \mathrm{X} 1+0,127 \mathrm{X} 2$. Dari hasil penelitian ini menyatakan bahwa ada pengaruh antara motivasi dengan kinerja bidang kesehatan di Puskesmas yang menjawab hipotesis penelitian yaitu ada pengaruh antara motivasi dengan kinerja bidang kesehatan, ada pengaruh pelayanan prima dengan kinerja bidang kesehatan, dan ada pengaruh motivasi dan pelayanan prima secara bersama-sama dengan kinerja bidang kesehatan di Puskesmas Tanjungsari Kabupaten Bogor.
\end{abstract}

Kata Kunci: motivasi; pelayan prima; kinerja

$\begin{array}{ll}\text { How to cite: } & \text { Harries Madiistriyatno dan Adi Setiawan (2021) Peningkatan kinerja bidang kesehatan, motivasi dan } \\ & \text { pelayanan prima, Syntax Idea 3(4). http://dx.doi.org/10.36418/syntax-idea.1107 } \\ \text { E-ISSN: } & \text { 2684-883X } \\ \text { Published by: } & \text { Ridwan Institute }\end{array}$




\section{Pendahuluan}

Masalah kesehatan masyarakat di negara-negara sedang berkembang pada prinsipnya menyangkut dua aspek. Pertama adalah aspek fisik, yaitu yang berhubungan dengan tingginya angka kelahiran dan kematian, masalah penyakit menukar, rendahnya mutu sanitasi lingkungan, tingginya penyakit kekurangan gizi dan sebagainya. Aspek yang kedua adalah aspek non-fisik yaitu yang berkaitan dengan tanggapan masyarakat terhadap sehat,sakit, serta hal-hal yang berhubungan dengan itu seperti masalah ketidaktahuan (ignorancy) dan rendahnya pengetahuan, kesadaran, dan sikap terhadap sehat-sakit, gizi/makanan, sanitasi, fasilitas dan sebagainya (Ryadi, 2016).

Aspek non-fisik dibidang kesehatan masyarakat pada hakekatnya mengangkut perilaku kesehatan. Terhadap pelayanan pada bidang kesehatan didapatkan pusat layanan kesehatan seperti rumah sakit, klinik, ataupun puskesmas (Hardiyanti, 2017).

Sebagai sebuah organisasi yang kompleks dengan padat karya, padat teknologi, dan padat profesi, maka untuk kebutuhan pelanggan diperhatikan semaksimal mungkin dengan memberikan pelayan prima sehingga pelanggan mendapatkan kepuasan. Dalam melaksanakan upaya-upaya dibidang kesehatan, puskesmas merupakan salah satu institusi pelayan kesehatan yang bertanggung jawab memberikan layanan yang bermutu tinggi bagi masyarakat dari kalangan menengah kebawah (Undang-undang nomor 23, 1992).

Puskesmas dalam melaksanakan tugasnya harus menjalankan beberapa fungsi, menyelenggarakan pelayan penunjang medis selain pelayanan medis dan non medis. Dari berbagai sumber disebutkan bahwa. Prinsip II (2) utama perbaikan mutu dan kinerja pelayanan kesehatan adalah kepedulian terhadap pelanggan. Pasien sebagai pelanggan eksternal tidak hanya menginginkan kesembuhan dari sakit yang diderita yang merupakan luaran (outcome) pelayan, tetapi juga merasakan dan menilai bagaimana ia diperlakukan dalam proses pelayanan (Muninjaya, 2019).

"Pusat pelayanan kesehatan masyarakat sebagai suatu unit organisasi yang bergerak dibidang pelayanan kesehatan yang berada di garda terdepan dan mempunyai misi sebagai pusat pengembangan pelayanan kesehatan, yang melaksanakan pembinaan dan pelayanan kesehatan secara menyeluruh dan terpadu untuk masyarakat disuatu wilayah kerja tertentu yang telah ditentukan secara mandiri dalam menentukan kegiatan namun tidak mencangkup aspek pembiayaan" (Situmorang, 2013).

Upaya peningkatan kinerja bidang kesehatan, berdasarkan pada (Undang-undang nomor 23, 1992). Oleh karenanya profesionalisme pegawai kesehatan sangat dibutuhkan terutama sesuai dengan standar dan pedoman pada tujuan pembangunan kesehatan yang pada hakekatnya mewujudkan Indonesia Sehat 2010, antara lain memuat harapan agar penduduk Indonesia memiliki untuk menjangkau pelayanan kesehatan yang bermutu, adil, dan merata. Puskesmas adalah sebagai ujung tombak pelayanan kesehatan dasar dalam mewujudkan komitmen peningkatan mutu layanan kesehatan (Lidya Aminatin, 2010).

Sebagai sebuah organisasi, puskesmas mempunyai peran dan tanggungjawab. Adapun ruang lingkup peran puskesmas adalah yang tercangkup pada penilaian kinerja 
puskesmas yang telah ditetapkan oleh Kementerian Kesehatan. Meliputi pada layanan kesehatan yang tercangkup pada kebijakan nasional, yang telah ditetapkan oleh Kementerian Kesehatan dan jenis layanannya disusun oleh Dinas Kesehatan kabupaten/kota, pelaksanaan manajemen yang terdiri dari proses penyusunan, perencanaan, dan pelaksanaan lokakarya dan manajemen SDM (Fitriyanti, 2016). Mutu layanan puskesmas dinilai pada standar yang ditetapkan sampai pada pengukuran pada tingkat kepuasan pengguna jasa layanan kesehatan dipuskesmas (Butar-Butar \& Simamora, 2016).

Kinerja bidang kesehatan di puskesmas, sama artinya dengan memberikan layanan yang bermutu. Hal ini dipengaruhi banyak faktor-faktor terutama pada 3(tiga) perubahan besar, yang memberikan tantangan dan peluang. Perubahan itu adalah (1) sumberdaya yang terbatas, (2) adanya kebijakan desentralisasi dan (3) berkembangnya kesadaran akan pentingnya mutu dalam layanan kesehatan (Calundu, 2018).

Salah satu faktor meningkatnya kinerja sebagai yang profesional, cepat, bersih, ramah, dan pelayan yang memberi kepuasan dan kesembuhan bagi pasien, adalah terlihat dari sumber daya fisik maupun sumber daya manusia. Sumber daya fisik menuju kinerja yang baik adalah sarana dan prasarana yang memadai, meliputi ruangan, alat kesehatan utama, alat diagnostik dan alat penunjang diagnostik serta alat kesehatan untuk suatu tindakan medik. Disamping itu juga tidak kalah pentingnya sumber daya manusia yang memenuhi syarat, baik kuantitas maupun kualitas. Petugas yang mempunyai pengetahuan yang tinggi, keterampilan yang andal dan tingkah laku yang baik (Etlidawati \& Handayani, 2017).

Pada aspek sumber daya manusia sangat erat kaitanya dengan tenaga kesehatan, baik dilihat dari motivasi maupun pelayanan prima yang ada pada tiap-tiap personel pegawai yang ada di Puskesmas. Kinerja suatu institusi pelayanan kesehatan akhir-akhir ini banyak menjadi sorotan, terutama sejak timbulnya iklim yang lebih demokratis dalam pemerintahan. Hal ini tentu saja terkait dengan masalah ketenagaan dalam suati institusi pelayanan kesehatan yang bersifat substansif, mengingat fungsi tenaga kesehatan sebagai pemberi jasa layanan kesehatan sangatlah kompleks. Sehingga perlu ada usaha sadar dalam mencermati faktor-faktor yang mempengaruhi kinerja tenaga paramedis disebuah layanan kesehatan (Etlidawati \& Handayani, 2017).

Mutu kinerja puskesmas sangat menentukan efisiensi terutama pada tingakt kinerja yang sering digolongkan pada mutu layanan kesehatan. Pelayanan prima yang bermutu rendah tidak dapat menyokong pada kinerja bidang kesehatan di Puskesmas dalam usaha mendapatkan surplus keuangan malah bisa sebagai penyebab kebangrutan. Walaupun kenyataannya Puskesmas diarahkan pada warga menengah bawah dengan kemampuan ekonomi yang sangat bervariatif. Beberapa orang menganggap SDM aset yang sangat mahal, namun beberapa orang tidak menggolongkan SDM sebagai aset karena dari segi akunting SDM tidak mempunyai nilai jualnya. Pada kenyataan ya dipuskesmas SDM yang terampil dan berdedikasi tinggi sangat dibutuhkan dan memang suatu hal yang langka. Sehingga dam mencapai tingkatan itu perlu adanya motivasi dari 
berbagai pihak secara internal maupun eksternal dalam meningkatkan layanan pada bidang kesehatan dipuskesmas (Wahyu, 2015).

Motivasi dikenal sebagai dorongan yang timbul dari hati seseorang untuk melakukan sesuatu dalam mencapai tujuan. Dipengaruhi berbagai faktor yang dimulai pada konsep dorongan kebutuhan. Motivasi seringkali merusak kegiatan seseorang. Timbulnya kebutuhan seseorang untuk memenuhi kebutuhan hidupnya menimbulkan dorongan manusia untuk melakukan sesuatu. Sehingga faktor kompensasi seringkali menjadi penyebab produktivitas kinerja pegawai dalam menjalankan tugasnya (Daud, 2012).

Kompensasi yang diterima tenaga kesehatan sangat mempengaruhi pada tingkat layanan kesehatan yang ada dipuskesmas. Konsumen sebagai pengguna jasa telah mendapatkan perlindungan secara hukum dengan munculnya (Undang-undang No.8, 1999) tentang perlindungan konsumen telah menuntut perawat sebagai pemberi jasa untuk mampu memberikan pelayanan bermutu sesuai standar yang ditentukan. Termasuk dari semua tenaga paramedis yang ada dipuskesmas. Maka dari itu perlu adanya peningkatan kinerja yang dibarengi oleh motivasi yang timbul dari dalam maupun luar tenaga medis.

Penelitian tentang faktor-faktor yang mempengaruhi pada tingkat kinerja bidang kesehatan dipuskesmas saat ini masih sangat kurang diminati. Terutama pada aspek motivasi dan pelayanan prima yang ada pada diri tenaga kesehatan sebagai pemberi jasa kesehatan. Oleh karena itu perlu kiranya diadakan penelitian tentang hal-hal yang berkaitan dengan hal-hal diatas. Semakin tinggi kesadaran masyarakat akan pentingnya kualitas layanan kesehatan dipuskesmas akan mendorong dan secara tidak langsung menuntut perawat dan tenaga medis lainnya untuk mampu memberikan pelayanan kesehatan yang bermutu sesuai dengan standar yang telah ditentukan(Daulay, 2020).

Tujuan penelitian ini adalah untuk mengetahui seberapa besar kinerja bidang kesehatan, motivasi dan pelayanan prima.

\section{Metode Penelitian}

Data penelitian diperoleh langsung dari tenaga yang ada dan pasien yang datang berobat disaat waktu penelitian di Puskesmas Tanjungsari Kabupaten Bogor, sehingga datanya bersifat primer yaitu dengan cara memberikan instrument. Data penelitian terdiri dari tiga jenis data yaitu : (1) data penelitian Motivasi terhadap Kinerja Bidang Kesehatan di Puskesmas Tanjungsari Kabupaten Bogor diperoleh dengan cara mengambil data dari sumber sekunder yaitu melalui data ketenagaan yang ada pada puskesmas, dan (2) data penelitian layanan prima terhadap Kinerja Bidang Kesehatan di Puskesmas Tanjungsari Kabupaten Bogor dengan cara memberikan soal non tes atau koesioner, dan (3) data penelitian kinerja Bidang Kesehatan di Puskesmas Tanjungsari Kabupaten Bogor diperoleh dengan cara memberikan non tes atau kuesioner kepada tenaga paramedis. 
Sementara itu, teknik pengambilan sampel yang digunakan adalah teknik qouta random sampling. Sehinga total dari jumlah responden adalah 60 responden pada November-Desember 2019.

\section{Hasil dan Pembahasan}

\section{A. Hasil Penelitian}

Penelitian mengenai pengaruh motivasi dan layanan prima terhadap kinerja karyawan ini akan di uji menggunakan uji regresi dan uji korelasi. Setelah itu dilanjutkan dengan uji hipotesis.

1. Pengaruh antara Motivasi (X1) dengan Kinerja Bidang Kesehatan (Y).

Analisis regresi linier sederhana $\mathrm{Y}$ atas $\mathrm{X} 1$ menghasilkan persamaan garis linier $\mathrm{Y}=34,226+0,366 \mathrm{X} 1$ artinya terdapat pengaruh positif antara Motivasi dengan Kinerja bidang Kesehatan. Kemudian dapat ditarik kesimpulan peningkatan suatu unit nilai pada motivasi menyebabkan peningkatan sebesar 0,2450 unit pada kinerja bidang kesehatan pada konstanta 34,226.

Analisis korelasi sederhana antara X1 dan Y menghasilkan koefisiensi korelasi (ry) sebesar 0,416 pengujian keberartian koefisiensi korelasi dengan menggunakan uji $-\mathrm{t}$ menghasilkan thitung $=3.487$ dari daftar distribusi untuk $\mathrm{db}$ = 58 dan taraf signifikansi 0,05 diperoleh t tabel sebesar 1,67 tampak bahwa nilai $\mathrm{t}$ yang diperoleh dari analisis (thitung) lebih kecil daripada t yang terdapat pada tabel (ttabel) hal ini menunjukan bahwa t hitung signifikansi, dan oleh karenanya koefisiensi korelasi sebesar 0,416 pun signifikansi.

Koefisiensi determinasi adalah kuadrat dan koefisiensi korelasi antara X1 dan $\mathrm{Y}$ yaitu sebesar $(0,416) 2=0,832$; ini menunjukan bahwa sekitar 8,32\% variasi yang terjadi pada motivasi dapat dijelaskan oleh Variasi kinerja bidang kesehatan melalui persamaan regresi $\mathrm{Y}=34,226+0,366 \mathrm{X} 1$. Dengan demikian hipotesis nol (H0) sebagaimana dinyatakan diatas ditolak, sebaliknya hipotesis alternatif diterima. Kesimpulannya ialah terdapat pengaruh positif antara motivasi dengan kinerja bidang kesehatan.

2. Pengaruh antara Pelayanan Prima (X2) dengan Kinerja bidang Kesehatan (Y)

Analisis regresi linier sederhana $\mathrm{Y}$ atas $\mathrm{X} 2$ menghasilkan persamaan garis regresi linier Y $47.215+0.123 \mathrm{X} 2$ persamaan garis regresi tersebut cukup berarti dan linier. Dengan demikian dapat di tarik kesimpulan pengaruh peningkatan suatu unit nilai pada pelayanan prima menyebabkan peningkatan sebesar 0,0123 unit nilai pada kinerja bidang kesehatan pada konstanta 47.215.

Pengujian keberartian koefisiensi korelasi dengan menggunakan uji $-\mathrm{t}$ menghasilkan thitung $=1,828$ dari daftar distribusi untuk $\mathrm{db}=58$ dan taraf signifikansi 0,05 diperoleh ttabel sebesar 1,67 tampak bahwa nilai $t$ yang diperoleh dari analisis (thitung) lebih kecil daripada $t$ yang terdapat pada tabel (ttabel) hal ini menunjukan bahwa thitung signifikansi. 
3. Pengaruh antara Motivasi (X1) dan Pelayanan Prima (X2) secara bersama-sama dengan Kinerja bidang Kesehatan (Y)

Dari hasil perhitungan analisis regresi jamak diperoleh persamaan garis $\mathrm{Y}=$ $27.591+0,370 \mathrm{X} 1+0,127 \mathrm{X} 2$. Analisis korelasi jamak antara X1 dan X2 dengan Y menghasilkan koefisien korelasi (ry 12) sebesar 0,481. Menghasilkan harga Ftuna cocok adalah 3,703 sedangkan Ftabel sebesar 3,15; artinya signifikan, karena Fhitung < Ftabel, hal ini menunjukan bahwa persamaan regresi $\mathrm{Y}=27.591$ $+0,370 \mathrm{X} 1+0,127 \mathrm{X} 2$ dapat dipertanggungjawabkan untuk menarik kesimpulan mengenai pengaruh secara bersama-sama antara Motivasi dan Pelayanan Prima secara bersama-sama dengan Kinerja bidang Kesehatan tampak bahwa nilai Fhitung < Ftabel. Hal ini menunjukan bahwa Fhitung signifikan. Dengan demikian hipotesis nol (H0) yang dinyatakan diatas ditolak dan konsekuensinya hipotesis alternatif (H1) diterima. Kesimpulannya ialah terdapat pengaruh yang positif antara Motivasi dan Pelayanan Prima secara bersama-sama dengan Kinerja bidang Kesehatan.

\section{B. Pembahasan}

Dalam pembahasan penelitian ini dilakukan dari dua segi, yaitu hasil deskripsi tiap variabel dan hasil analisis korelasi antar variabel. Hasil analisis deskripsi tiap variabel menunjukan bahwa:

Pertama, variabel motivasi diperoleh rentang skor antara 47 sampai dengan 58 dengan rata-rata observasi sebesar 52.5667. Kedua, variabel Pelayanan prima diperoleh rentang skor antara 38 sampai dengan 55 dengan rata-rata observasi sebesar 50.8833. Ketiga, variabel kinerja bidang kesehatan memperoleh rentang skor antara 50 sampai dengan 57 dengan rata-rata observasi 53.4667.

Berdasarkan hasil deskripsi setiap variabel penelitian menunjukan pengaruh antara Motivasi (X1) dan Pelayanan Prima (X2) secara bersama-sama dengan Kinerja bidang Kesehatan (Y) karena keberhasilan pelayanan kesehatan melalui puskesmas memberikan konstribusi yang cukup besar didalam mewujudkan Indonesia Sehat 2010. Berbagai masalah yang timbul dalam mewujudkan kondisi tersebut telah dicoba diatasi dengan diluncurkannya kebijakan dasr puskesmas yang merupakan bagian dari reformasi kesehatan (health reform).

Sesuai dengan health reform, fungsi puskesmas yang tadinya lebih berorientasi kepada upaya kuratif dan rehabilitatif, bergeser kepada upaya preventif dan promotif tanpa mengabaikan upaya kuratif dan rehabilitatif. Fungsi puskesmas juga makin kompleks yakni sebagai pusat pemberdayaan masyarakat serta pusat pelayanan kesehatan masyarakat strata pertama yaitu meliputi pelayanan kesehatan perorangan (private good) dengan tujuan utama memelihara dan meningkatkan derajat kesehatan masyarakat serta mencegah penyakit tanpa mengabaikan upaya kuratif dan rehabilitatif.

Penyebaran SDM kesehatan yang masih menjadi kendala, sekalipun sejak tahun 192 telah diterapkan kebijakan penetapan tenaga dokter dan bidan dengan 
sistem PTT. Sampai dengan tahun 2006 tercatat rasio dokter terhadap puskesmas untuk kawasan Indonesia bagian barat jauh lebih tinggi dibandingkan dengan kawasan Indonesia timur yang berkisar antara 0,84 di Sumatera Utara dan 0,12 di Papua. Rendahnya rasio tenaga kesehatan terhadap puskesmas maupun terhadap jumlah penduduk disuatu daerah sangat dipengaruhi oleh kondisi geografis lokasi puskesmas.

Oleh karena itu diperlukan suatu strategi untuk meningkatkan minat tenaga kesehatan bekerja di puskesmas. Dan dengan adanya ratio yang kurang dari harapan, solusi yang terbaik adalah dengan meningkatkan kinerja para tenaga yang ada. Karena kinerja sangat berkaitan sekali dengan produktivitas seseorang dalam menghasilkan sebuah kerja.

Kinerja merupakan prestasi kerja. Hal ini berarti aktivitas dinyatakan berprestasi jika ada standar yaitu berupa persyaratan-persyaratan yang merupakan indikator yang mengukur suatu prestasi kerja, disini aktivitas kerja pegawai dinilai dan diukur sesuai standar yang tercantum pada surat keputusan Menteri Kesehatan. Secara perhitungan statistik hubungan antara motivasi dan pelayanan prima dengan peningkatan kinerja bidang kesehatan di Puskesmas Tanjungsari Kabupaten Bogor digambarkan pada persamaan regresi $\mathrm{Y}=34.226+0,366$, dengan nilai konstribusi sebesar 0,416, artinya 41,6\% kinerja bidang kesehatan dipengaruhi oleh faktor motivasi dan pelayanan prima.

Pada kenyataannya faktor motivasi bukanlah satu-satunya faktor yang memberikan konstribusi pada peningkatan kinerja bidang kesehatan, yang dalam penelitian ini ada faktor Motivasi digambarkan oleh Abraham Maslow sebagai sebuah kebutuhan akan dorongan untuk mencapai tujuan. Sehingga motivasi kadang disebut sebuah proses atau penguatan seseorang untuk melakukan sesuatu. Faktor ini mempengaruhi pada setiap pegawai, tanpa adanya dorongan ini seseorang tidak akan mempunyai sinergi untuk melakukan sesuatu, walaupun itu sudah menjadi sebuah profesi. Hasil perhitungan statistik yang menggambarkan hubungan antara motivasi tenaga paramedis dengan peningkatan kinerja bidang kesehatan di Puskesmas Tanjungsari Kabupaten Bogor adalah persamaan regresi $\mathrm{Y}=47.215+0.123 \mathrm{X} 2$ dengan nilai konstribusi sebesar 0,233, artinya faktor motivasi memberikan 23,3\% konstribusi pengaruh pada peningkatan kinerja bidang kesehatan di Puskesmas Tanjungsari Kabupaten Bogor.

Hasil korelasi antar variabel menunjukkan bahwa baik secara sendiri-sendiri maupun bersama-sama motivasi tenaga dan pelayanan prima mempunyai hubungan positif dengan peningkatan kinerja bidang kesehatan di Puskesmas Tanjungsari Kabupaten Bogor. Hubungan tersebut memiliki arti bahwa pelayanan prima yang berpengaruh pada produktivitas seorang pegawai dengan hasil gaungan dengan faktor dengan motivasi akan menghasilkan sebuah unit peningkatan kinerja dalam bidang kesehatan di Puskesmas Tanjungsari Kabupaten Bogor. Artinya meningkatnya kinerja yang berorientasi pada pengurangan angka kematian bayi dan ibu melahirkan sebagai sebuah fungsi dari puskesmas yang memberikan layanan 
kesehatan kepada masyarakat bawah dipengaruhi oleh dua faktor secara bersamaan yaitu motivasi dan pelayanan prima dengan hasil perhitungan statistik dengan persamaan regresi $\mathrm{Y}=27,591+0.370 \mathrm{X} 1+0.127 \mathrm{X} 2$ dengan nilai konstribusi sebesar 0,481 atau $4,81 \%$, sisanya dipengaruhi oleh faktor lain yang tidak terteliti oleh peneliti pada kesempatan penelitian ini.

\section{Kesimpulan}

Berbagai kegiatan penelitian yang telah dilakukan dapat diuraikan bahwa berdasarkan hasil analisis data dan hasil pengujian hipotesis ditemukan bahwa faktor motivasi berpengaruh terhadap peningkatan kinerja bidang kesehatan dengan nilai korelasi (ry $1=0,416$ ). Hal tersebut berarti seorang yang memiliki persepsi yang baik terhadap motivasi dan memberikan pelayanan prima yang tinggi, ia akan menunjukkan prestasi kerja yang baik pula dalam bentuk produktivitas kerja yang menghasilkan kinerja bidang kesehatan di Puskesmas Tanjungsari Kabupaten Bogor. Jadi keberhasilan kinerja bidang kesehatan di Puskesmas dapat diantisipasi atas dasar persepsi terhadap kinerja yang diasumsikan berorientasi pada produktivitas. Hal ini dapat dilihat melalui persamaan regresi $\mathrm{Y}=34.226+0.366 \mathrm{X} 1$

Selain itu, hubungan antara pelayanan prima dengan kinerja bidang kesehatan di Puskesmas memiliki koefisien korelasi sebesar ry $2=0,233$; hal tersebut menunjukkan bahwa 23,3\% variasi keberhasilan kinerja bidang kesehatan dapat dijelaskan hubungannya dengan pelayanan prima. Hubungan antara motivasi dan keberhasilan pelayanan prima ditunjukan pula koefisien arah regresi sederhana $b=0,123$ dan konstanta sebesar $\mathrm{a}=47.215$. Bentuk hubungan antar kedua variabel tersebut dapat dijelaskan melalui persamaan regresi sederhana $\mathrm{Y}=47.215+0,123 \mathrm{X} 2$ dengan demikian seorang yang memiliki motivasi dan memberikan pelayanan prima yang tinggi, ia mempunyai sumbangan terhadap keberhasilan pada kinerja bidang kesehatan.

Kinerja bidang kesehatan di Puskesmas dapat pula diprediksi atas dasar motivasi tenaga yang ada di Puskesmas.

Apabila dilakukan pengendalian dalam arti menghilangkan variabel motivasi dan pelayana prima, maka akan memiliki koefisien korelasi sebesar ryl, $2=0,233$. Hal ini ini menunjukkan bahwajika dilakukan pengendalian terhadap motivasi dan pelayanan prima $25,77 \%$, variasi motivasi terhadap kinerja bidang kesehatan dapat dijelaskan hubungan melalui persepsi tentang motivasi dan kinerja bidang kesehatan.

Hubungan jamak antara motivasi dan pelayanan prima dengan kinerja bidang kesehatan adalah sebesar ryl,2 $=0,481$. Yang dapat dilihat pada persamaan regresi ganda $\mathrm{Y}=27,591+0,370 \mathrm{X} 1+0,127 \mathrm{X} 2$.

Dari perhitungan yang dilakukan, baik secara tunggal maupun jamak, diperoleh gambaran bahwa dilakukan atau tidak keberhasilan pengendalian koefisien, korelasi antara motivasi dan pelayanan prima memiliki koefisien korelasi cukup signifikan dengan kinerja bidang kesehatan.

Meskipun ada perbedaan kadar hubungan jika dilakukan pengendalian namun terdapat peningkatan kadarnya relatif kecil bila dibandingkan dengan korelasi ganda 
atau jamak, lebih terlihat lagi adanya peningkatan kadar hubungan. Dengan demikian, melibatkan lebih banyak faktor dalam mencapai keberhasilan kinerja bidang kesehatan di Puskesmas makin meningkatkan layanan tersebut.

\section{BIBLIOGRAFI}

Butar-Butar, Junita, \& Simamora, Roymond H. (2016). Hubungan Mutu Pelayanan Keperawatan dengan Tingkat Kepuasan Pasien Rawat Inap di RSUD Pandan Kabupaten Tapanuli Tengah. Jurnal Ners Indonesia, 6(1), 50-63.Google Scholar

Calundu, Rasidin. (2018). Manajemen Kesehatan (Vol. 1). Sah Media. Google Scholar

Daud, Firdaus. (2012). Pengaruh kecerdasan emosional (EQ) dan motivasi belajar terhadap hasil belajar Biologi siswa SMA 3 Negeri Kota Palopo. Jurnal Pendidikan Dan Pembelajaran (JPP), 19(2), 243-255. Google Scholar

Daulay, Nurhasanah. (2020). Analisis kualitas pelayanan jasa kesehatan pada puskesmas Desa sihepEng Kecamatan Siabu Kabupaten Mandailing Natal. IAIN Padangsidimpuan. Google Scholar

Etlidawati, Etlidawati, \& Handayani, Diyah Yulistika. (2017). Hubungan kualitas mutu pelayanan kesehatan dengan kepuasan pasien peserta jaminan kesehatan nasional. Medisains, 15(3), 142-147. Google Scholar

Fitriyanti, Rifky Umarella. (2016). Laporan tugas akhir asuhan kebidanan komprehensif pada NY." S" G3P2002 dengan faktor resiko usia lebih dari 35 tahun di wilayah kerja puskesmas Klandasan Ilir Kota Balikpapan. Google Scholar

Hardiyanti, Dina. (2017). Optimasi Pelayanan Kesehatan Dasar (Studi Pada Pusat Kesehatan Masyarakat (Puskesmas) Kuripan Kecamatan Kuripan Kabupaten Probolinggo). Universitas Brawijaya. Google Scholar

Lidya Aminatin, Fitria. (2010). Tanggung jawab apoteker menurut PerundangUndangan Di Indonesia. Universitas Wijaya Putra. Google Scholar

Muninjaya, A. A. Gde. (2019). Manajemen mutu pelayanan kesehatan. EGC. Google Scholar

Ryadi, Alexander Lucas Slamet. (2016). Ilmu kesehatan masyarakat. Penerbit Andi. Google Scholar

Situmorang, Chazali. (2013). Mutu pekerja sosial di era otonomi daerah. Cinta Indonesia. Google Scholar

Undang-undang No.8. (1999). Perlindungan konsumen. 
Harries Madiistriyatno dan Adi Setiawan

Undang-undang nomor 23. (1992). Kesehatan.

Wahyu, Mr. (2015). Analisis kepuasan terhadap pelayanan pasien Di Puskesmas Kapuas Kabupaten Sanggau. Um Pontianak. Google Scholar

\section{Copyright holder :}

Harries Madiistriyatno dan Adi Setiawan (2021)

\section{First publication right :}

Journal Syntax Idea

This article is licensed under:

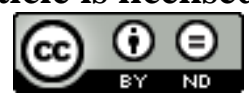

